\title{
Confirmed assignment of a novel human tyrosine kinase gene (JAK1A) to 1 p32.3 $\rightarrow$ p31.3 by nonisotopic in situ hybridization
}

\author{
W.S. Modi, ${ }^{1}$ W.L. Farrar, ${ }^{2}$ and O.M.Z. Howard ${ }^{3}$ \\ 'Biological Carcinogenesis and Development Program, Program Resources Inc./DynCorp.. NCI-Frederick Cancer Research and \\ Development Center. \\ 2Biological Response Modifiers Program. NCl-Frederick Cancer Research and Development Center; and \\ ${ }^{3}$ Biological Response Modifiers Program. Program Resources. Inc./Dyncorp, NCI-Frederick Cancer Research and Development \\ Center, Frederick, MD (US $A$ )
}

\begin{abstract}
JAK $1 \mathrm{~A}$ is a recently isolated class 3 (nonreceptor) tyrosine kinase that has catalytic domain sequence homology with other kinases and is known to be ubiquitously expressed in all human tissues thus far examined. The gene for this enzyme had previously been localized to chromosome 1 using somatic
\end{abstract}

cell hybrids and linkage analyses. In the present study, fluorescence in situ hybridization was utilized to confirm its localization and regionally assign the gene to chromosome region Ip $32.3 \rightarrow \mathrm{p} 31.3$.
Tyrosine phosphorylation has been demonstrated to play a central role in signal transduction from the cell membrane to the nucleus. With the increasing realization that kinases play important roles in every aspect of normal and abnormal cell growth and metabolism, it has become necessary to isolate and characterize the cDNAs and genes for these essential proteins.

Protein kinases are a group of enzymatic proteins that catalyze the phosphorylation of serine, threonine, or tyrosine residues. These kinases can be grouped into three major families, based upon the particular amino acid phosphorylated and whether they are located in the cell membrane as a receptor or in the cytoplasm. The first group includes the receptor kinases. which contain three structural components: a ligand-binding domain, a transmembrane domain, and a tyrosine kinase

Supported, at least in part, with Federal funds from the US Department of Health and Human Services under Contract No. NO1-CO-74102 with Program Resources. Inc. The content of this publication does not necessarily reflect the views or policies of the Department of Health and Human Services, nor does mention of trade names, commercial products, or organizations imply endorsement by the US Government.

Received 12 October 1992; revision accepted 12 September 1994.

Request reprints from Dr. William S. Modi. Biological Carcinogenesis and Development Program. Program Resources Inc./DynCorp., NCI-Frederick Cancer Research and Development Center. Frederick. MD 21702-1201 (USA): telephone: 301-846-1303: fax: 301-846-1909: c-mail: modi@incifcrf.gov. domain. The second class of tyrosine kinases is composed of proteins that lack the transmembrane domain but do contain a regulatory domain. $\mathrm{SH} 2$ or $\mathrm{SH} 3$. These are found primarily in the cytosol and are often associated with membrane proteins. The third class contains a group of nonreceptor kinases that have only recently been isolated and are poorly characterized at this time. These large proteins lack both a transmembrane and regulatory domain but do contain a classical tyrosine kinase domain and a degenerate kinase-like domain (Firmbach-Kraft et al., 1990).

Many kinases have been isolated based on catalytic domain homology (Hanks et al., 1988). The first method used low-st ringency library screening; more recently, PCR cloning of the conserved catalytic domain has been used. One such kinase. Jakl. has recently been sequenced (Wilks et al.. 1991). Jakl kinase is a member of the recently identified class 3 tyrosine kinases.

Jakl message has been detected in all human cell types tested to date (Wilks et al., 1991: Howard et al.. 1992). The other members of this kinase family (TYK2 and JAK2) have also been detected in all cell types. Kinase activity has not been demonstrated for the full-length Jakl protein. However, a fusion protein containing glutathione transferase and the classical kinase domain does have phosphorylating activity when expressed in bacterial cells (Wilks et al., 1991). In our studies. the steady-state message level of Jakl increased in human monocytes in response to $\gamma$-interferon. Recently Tyk 2 has been linked with the signal transduction pathway of $\alpha$ - and $\beta$-inter- 
feron (Velazquez et al., 1992). Thus, Jakl is a member of a unique kinase family and itself has several unique properties.

We have previously reported the assignment of the gene for Jak I (JAKIA) to human chromosome 1 by human $x$ rodent somatic cell hybrids and linkage studies using the CEPH database (Howard et al., 1992). Here, we report in situ hybridization results that confirm our initial assignment and sublocalize the gene to region $1 \mathrm{p} 32.3 \rightarrow \mathrm{p} 31.3$.

\section{Materials and methods}

A 2-kb fragment of Jak I cDNA cloned in Bluescript KS (Stratagene) containing both catalytic and degenerate kinase domains was used as a hybridization probe to metaphase chromosomes. The protocol utilized for fluorescence in situ hydridization is given in Hoehe et al. (1991). Metaphase chromosomes were derived from nomal donors and grown in short-term tissue culture for $96 \mathrm{~h}$. The Jak I cDNA clone was labeled with biotin-11. dUTP following nick translation and included in a $|0-\mu|$ volume containing $50 \mathrm{ng} / \mu l$ probe DNA and $300 \mathrm{ng} / \mu l$ sheared salmon sperm DNA in a solution of $50 \%$ formamide, $10 \%$ dextran sulfate, and $2 \times$ SSC. pH 7.0. Both the probe and chromosomal DNA were denatured, and hybridization occurred overnight at $37^{\circ} \mathrm{C}$. The slides were washed at $40^{\circ} \mathrm{C}$ in $50 \%$ formamide, $2 \times$ SSC and then three times ( 5 min each) in $2 \times$ SSC alone. Hybridization was detected by immersing the slides in a solution of $4 \times$ SSC, $3 \%$ bovine serum albumin containing $5 \mu \mathrm{g} / \mathrm{ml}$ fluorescein isothiocyanate (FITC)-conjugated avidin DCS. Slides were stained in Hoechst $33258(0.6 \mu \mathrm{g} / \mathrm{ml})$ for $20 \mathrm{~min}$. followed hy actinomycin $D(0.5 \mu \mathrm{g} / \mathrm{ml})$ for $25 \mathrm{~min}$ and then left overnight at $4^{\circ} \mathrm{C}$. Chromosomes were viewed in an antifade solution of $2 \% n$-propylgallate in $50 \%$ glycerol, $4 \times$ SSC containing $5 \mu \mathrm{g} / \mathrm{ml}$ propidium iodide.

\section{Results and discussion}

Examination of 37 metaphase cells indicated specific hybridization in 14 cells $(38 \%)$ to the region $1 \mathrm{p} 32.3 \rightarrow \mathrm{p} 31$. 3 . No significant background was observed at any other chromosomal locations (Fig. 1). These results enable assignment of JAK IA to this location.

Recently, the gene for Tyk2, the prototype of this tyrosine kinase family, was assigned to human chromosome band 19p13.2 (Firmbach-Kraft et al., 1990). With the assignment of JAK1A to human chromosome region $1 \mathrm{p} 32.3 \rightarrow \mathrm{p} 31.3$, it is now evident that the genes encoding these unique nonreceptor kinases are not clustered on a single chromosome. With the chromosomal assignment of JAKIA, we can begin to address the neoplasia potentially associated with this gene: There are two reported translocations that give rise to acute lymphoblastic leukemia with a breakpoint in Ip32 (Kaneko et al.. 1989; Raimondi et al., 1989). Additionally, two larger translocations or deletions have been identified in the region $1 \mathrm{p} 36 \rightarrow \mathrm{p} 32$. These structural abnormalities are reported to give rise to neuroblastoma or glioma (Franke et al., 1985; Jenkins et al., 1989). The human homolog of the murine myeloproliferative leukemia virus, which causes an acute leukemia, maps nearby at band Ip34 (Le Coniat et al.. 1989). Further studies of neoplasia associated with $1 \mathrm{p} 32.3 \rightarrow \mathrm{p} 31.3$ could demonstrate a function for the JAKI protein. Future studies of the intron/exon arrangement of JAKI could serve as a model for the genetic arrangement of other members of the class 3 tyrosine kinase family.
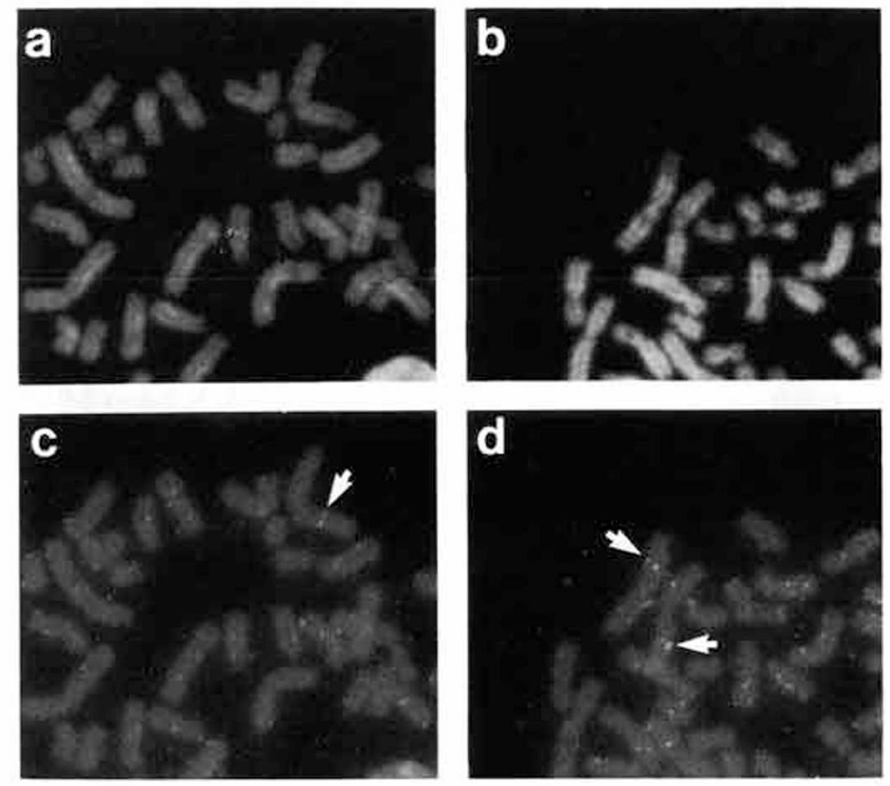

Fig. 1. Partial metaphase cells illustrating simultaneous QFH-banding with Hoechst 33258 (a. b) and fluorescence in situ hybridization with the Jak I cDNA clone (c, d). Arrows indicate paired hybridization signals on the short arm of chromosome I.FI

Fig. 2. Idiogram of chromosome I showing localization of JAKIA to region I p $32.3 \rightarrow$ p.31.3.

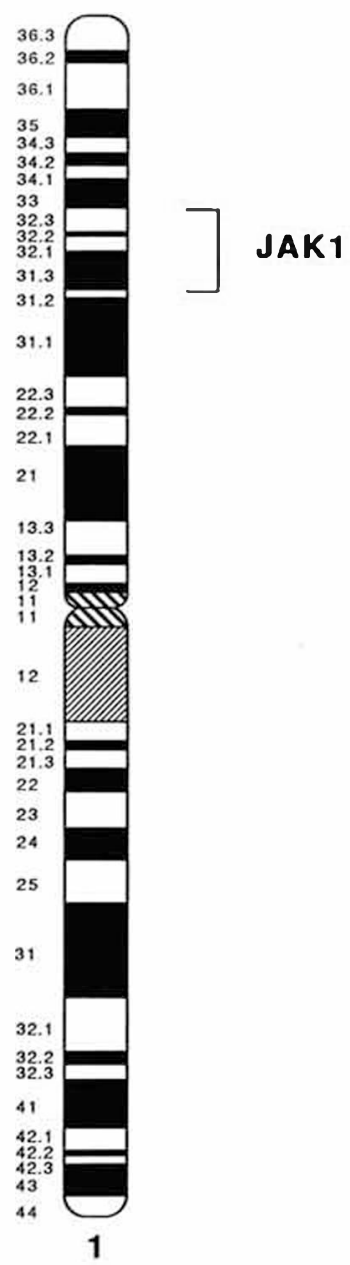




\section{References}

Firmbach-Kraft I, Byers M, Shows T, Dalla-Favera R Krolewski JJ: Tyk2, prototype of a novel class of non-receptor tyrosine kinase genes. Oncogene S: 1 329-1336 (1990)

Franke F. Forster W. Rudolph B. Laminer F: Metastat ic neuroblastoma in an infant: translocation (1:11) deletion (2) and double minute chromosomes. Eur J Pediatr 143:305-308 (1985).

Hanks SK. Quinn AM. Hunter T: The protein kinase family: conserved features and deduced phylogeny of the catalytic domains. Science 241:42-52 (1988).

Hoche MR, Cacnazzo L, Martinez MM. Hsich W-T Modi WS. Gershon WS. Bonner TI: Genetic and physical mapping of the human cannabinoid re ceptor gene to chromosome 6q14 $\rightarrow$ q 1 S. New Biologist 3:880-885 (1991).
Howard OMZ, Dean M. Young H. Ranisburg M. Tur pin JA. Michiel DF. Kelvin DJ, Lee L. Farrar WL: Characterization of a class 3 tyrosinc kinase. Oncogene 7:895-900 (199?).

Jenkins RB, Kimmel DW, Moenel CA, Schulı. CA Menezes RM. Scheithauer B. Kelly PJ. Dewald GW: Recurrent cytogenetic abnormalities in 80 human gliomas. Tenth International Workshop on Human Gene Mapping. Crtogenet Cell Genet $51: 1019$ (1989).

Kancko Y, Frizzera G, Shikano T, Kobayashi II, Maseki N, Sakurai M: Chromosomal and immunophe notypic patterns in T cell acule lymphoblastic leukemia (T ALL) and lymphoblastic lymphoma (LBL). Leukemia 3:886-89? (1989).
Le Coniat M. Souyri M. Vigon I. Wendling F. Tambou rin P. Benger R: The human homolog of the myeloproliferative virus maps to chromosome band I p34 Hum Genet 83:94-196 (1989).

Raimondi SC, Bchm FG, Carroll AJ, Rivera GK, Pui CH, Mirro J, Williams DL: New nonrandom translocations in childhood acute lymphoblastic leukemia (ALL). Tenth international Workshop on Human Gene Mapping. Cytogenet Cell Gent 51:1063 (1989).

Velazque: L. Fellous M, Stark GR. Pellegrini S: A protein tyrosine kinase in the interferon $\omega / \beta$ signaling pathway. Cell 70:313-322 (1992).

Wilks AF. Harpur AG, Kurban RR, Ralph SJ, Zurcher G, Ziemiecki A: Two novel protein-tryosine kinases, each with a second phosphotransferaserelated catalytic domain, define a new class of protcin hinase. Mol Cell Biol 11:2057-2065 (1991). 